\title{
A novel protein chip for simultaneous detection of antibodies against four epidemic swine viruses in China
}

\author{
Yue $\mathrm{Wu}^{1 \dagger}$, Xudan $\mathrm{Wu}^{1 \dagger}$, Jing Chen ${ }^{1}$, Jingfei $\mathrm{Hu}^{2}$, Xiaobo Huang ${ }^{2}$ and Bin Zhou ${ }^{1 *}$ (D)
}

\begin{abstract}
Background: At present, pig industry in China is faced with the complex situation of mixed infection caused by multiple pathogens. It is urgent to develop some new high-throughput molecular diagnosis assays to simultaneously detect pathogens or antibodies. Biochip array technology has made it possible to screen thousands of samples simultaneously; it has been twice named as one of the top 10 scientific and technological breakthroughs. Studies have reported encouraging results using protein biochips for detecting antibodies against avian infectious bronchitis virus and ruminant bluetongue virus, but the research of this technology for the diagnosis of swine diseases is still sparse.

Results: In this study, a novel protein chip was developed that can simultaneously detect the antibodies of four important swine viruses as follow, classical swine fever virus (CSFV), porcine parvovirus (PPV), Japanese encephalitis virus (JEV), and porcine reproductive and respiratory syndrome virus (PRRSV). Four prokaryotic expression plasmids pET-32a-E2 of CSFV, -VP2 of PPV, -EDIII of JEV, and -N of PRRSV were induced by IPTG (Isopropyl $\beta$-D-1-

Thiogalactopyranoside) and overexpressed in E.coli, respectively. The purified proteins were identified by Western blotting and then printed on epoxy-coated glass slides. The optimized parameters of this diagnostic chip showed that the spotting concentrations of E2、VP2、EDIII、N proteins were $0.2,0.4,0.4$, and $0.4 \mathrm{mg} / \mathrm{mL}$. The optimal primary and secondary antibody dilutions were 1:50 and 1: 600. Compared with the commercial ELISA (Enzymelinked immunosorbent assay) kits, the positive and negative coincidence rates of this chip were $95.8 \% \sim 100$ and $86.2 \% \sim 100 \%$, as well as, no cross-reaction.

Conclusion: This protein chip provided a fast, specific, and sensitive method for simultaneous detection of antibodies in clinical serum samples. Compared with traditional methods, this protein chip can monitor very small amount of serum.
\end{abstract}

Keywords: Protein biochip, Simultaneous detection, Swine diseases, antibodies

\section{Background}

With the increase in scale of pig production, diseases of pigs have come to have an enormous impact on pork

\footnotetext{
* Correspondence: zhoubin@njau.edu.cn

†Yue Wu and Xudan Wu contributed equally to this work.

${ }^{1}$ MOE Joint International Research Laboratory of Animal Health and Food

Safety, College of Veterinary Medicine, Nanjing Agricultural University, Nanjing 210095, China

Full list of author information is available at the end of the article
}

producers and often on the economy of pork producing countries. China, the world's largest pork producer, stands to shoulder very large economic losses from swine diseases [1]. In large scale production practices, epidemic disease problems can be divided into three general categories. First, the occurrence of mixed infections or secondary infections, both cause high rates of morbidity and mortality [2, 3]. Second, the overlap of disease syndromes, such as reproductive disorders,

(c) The Author(s). 2020 Open Access This article is licensed under a Creative Commons Attribution 4.0 International License, which permits use, sharing, adaptation, distribution and reproduction in any medium or format, as long as you give appropriate credit to the original author(s) and the source, provide a link to the Creative Commons licence, and indicate if changes were made. The images or other third party material in this article are included in the article's Creative Commons licence, unless indicated otherwise in a credit line to the material. If material is not included in the article's Creative Commons licence and your intended use is not permitted by statutory regulation or exceeds the permitted use, you will need to obtain permission directly from the copyright holder. To view a copy of this licence, visit http://creativecommons.org/licenses/by/4.0/ The Creative Commons Public Domain Dedication waiver (http://creativecommons.org/publicdomain/zero/1.0/) applies to the data made available in this article, unless otherwise stated in a credit line to the data. 
difficult breathing, diarrhea, fever, makes it difficult to identify a specific disease [4]. Third, under pressure from vaccination and antibiotic treatment, new strains of familiar pathogens, as well as new pathogens, are leading to large scale outbreaks [5-7]. These conditions make it necessary to develop diagnostic assays that can quickly and reliably screen large numbers of clinical samples. This will allow a savings of clinical manpower and material resources, as well as reduce the mortality and morbidity of pigs [8-10].

Biochip array technology has made it possible to screen thousands of samples simultaneously; it has been twice named as one of the top 10 scientific and technological breakthroughs [11]. The protein biochip is a novel application of the sandwich-type antibody-capture assays, such as ELISA, the fundamental difference is that the capture proteins are covalently attached to the surface of the biochip in an ordered array. The microarray format also enables a highly integrated analysis [12-14]. The development of multi-level biochips will enable high-throughput quantitative and qualitative diagnosis of important pig diseases and will help solve current diagnostic needs for large number of animal diseases [15]. Studies have reported encouraging results using protein biochips for detecting antibodies against avian infectious bronchitis virus and ruminant bluetongue virus, but the research of this technology for the diagnosis of swine diseases is still sparse [14]. To date, there are few commercial protein biochips available for use in pig diagnostics [16, 17]. Therefore, protein biochips should be developed to meet domestic demand and promote the healthy development of the pig breading industry in China.

In this study, four proteins, the E2 protein of Classical Swine Fever Virus (CSFV)VP2 of Porcine Parvovirus (PPV), domain III of the E protein of Japanese Encephalitis Virus (JEV), and the N protein of Porcine Reproductive and Respiratory Syndrome Virus (PRRSV), were used as capture antigens to develop a fluorescent based detection assay for simultaneous screening serum samples. After protein, buffer, and antibody parameters were optimized, we found that the detection rate for positive samples was above $95 \%$, with no cross-reaction. This protein biochip has the advantages of quick and simple operation with high sensitivity and specificity.

\section{Results}

\section{Expression and purification of fusion proteins}

The four gene fragments were successfully amplified by PCR (Polymerase chain reaction), double-digested, and then cloned into pET-32a vectors. Plasmid constructs were verified by PCR and DNA sequencing and restriction enzyme digestion. SDS-PAGE analysis of the purification of transformed, IPTG induced bacteria, showed that the CSFV-E2 fusion protein $(35 \mathrm{kDa})$ was expressed in the supernatant and inclusion bodies, while the PPVVP2, JEV-EDIII, and PRRSV-N fusion proteins $(30 \mathrm{kDa})$ were expressed only in inclusion bodies. These results demonstrate that each protein was expressed successfully and that high purity protein was obtained after $\mathrm{Ni}$ column purification (Fig. 1).

\section{Optimization of the protein chip assay Antigen concentration}

All proteins were diluted to $0.4,0.2,0.1,0.05,0.025 \mathrm{mg} /$ $\mathrm{mL}$. Scanning analysis showed that for the CSFV-E2 protein, $0.2 \mathrm{mg} / \mathrm{mL}$ was the optimal concentration, and for PPV-VP2, JEV-EDIII, and PRRSV-N $0.4 \mathrm{mg} / \mathrm{mL}$ was the optimal (Fig. 2).

\section{Print buffer}

The print buffers tested were $40 \%$ vol (volume) and $50 \%$ vol commercial buffer, and 50\% homemade buffer, as well as the negative control of $2 \%$ BSA (Bovine serum albumin). 50\%vol commercial buffer resulted in discrete fluorescence spots with little or no smearing. $40 \%$ commercial, and 50\% homemade buffer resulted in spots with moderate to substantial smearing (Fig. 3).

\section{Antibody dilution and incubation time}

The optimal dilution for primary antibodies against CSFV-E2, PPV-VP2, JEV-EDIII and PRRSV-N was 50fold with $1 \mathrm{~h}$ incubation time at $37^{\circ} \mathrm{C}$. The optimal dilution of the $\mathrm{Cy} 3$ secondary antibody was 600 -fold with an incubation time of $45 \mathrm{~min}$ at $37^{\circ} \mathrm{C}$. The signal to noise ratios for each sample was determined by testing 20 sera negative for all the fusion proteins.

\section{Cut-off value for determination of four viral antibodies}

Twenty serums known to be negative for CSFV, PPV, JEV and PRRSV were 50-fold diluted and then were incubated with the prepared protein chips for $1 \mathrm{~h}$ at $37^{\circ} \mathrm{C}$. The CaptialBio Luxscan-10 K/A chip scanner was used to calculate the SNR value (median signal intensity to background median). Dates are shown in Table 1. The results show that when the SNR value of CSFV, PPV, JEV and PRRSV exceeded 1.78, 2.35, 3.38, and 1.28, respectively, the sample can be judged as antibody positive, otherwise antibody negative.

\section{Specificity, repeatability, and stability}

The four fusion proteins were printed at their optimized concentration in triplicate in an array, and the array was printed in triplicate. Each array was incubated with a specific protein-positive serum. The resulting fluorescent spots were protein specific as can be seen in Fig. 4. The results revealed that the arrays incubated with CSFV, 

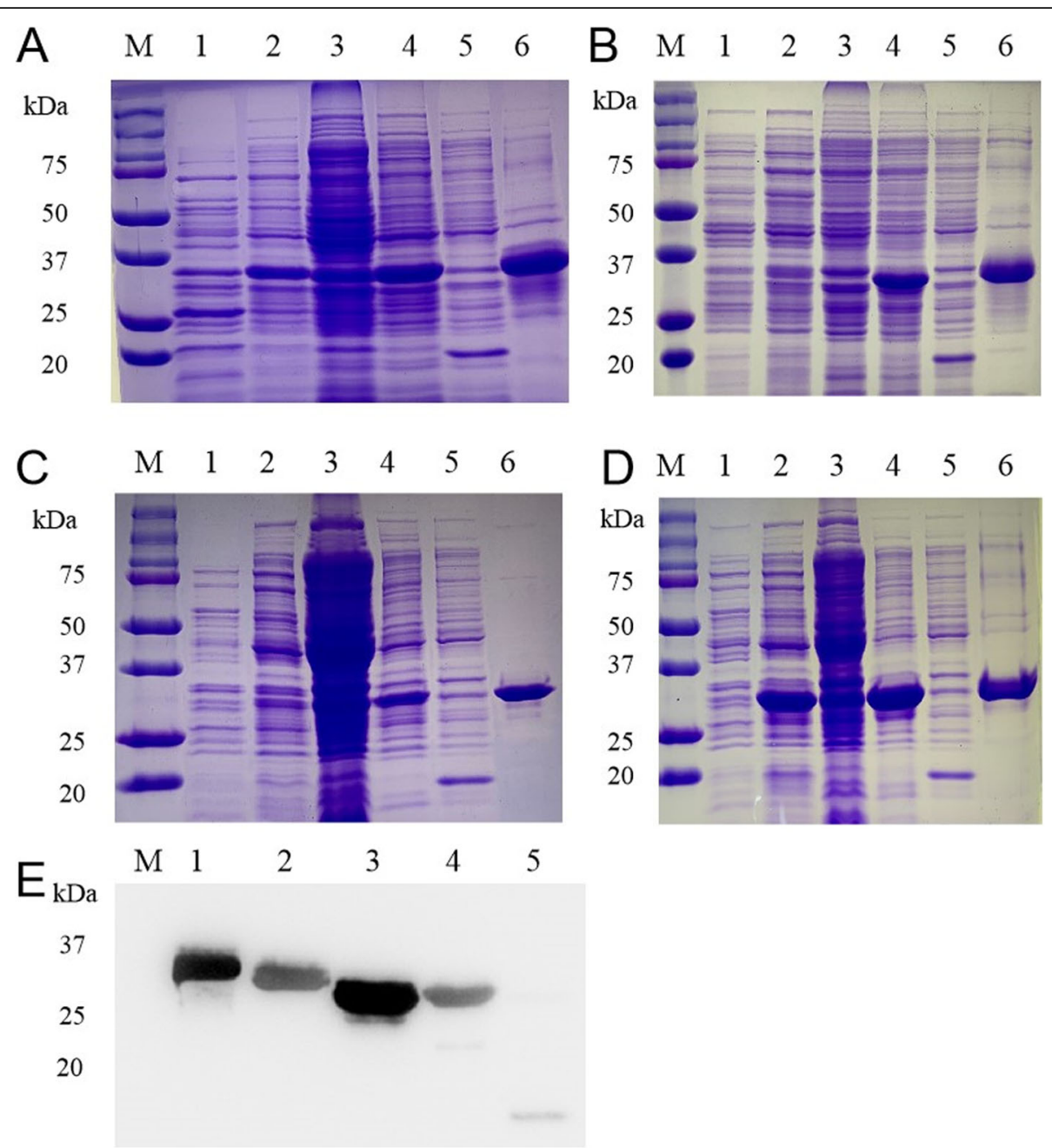

Fig. 1 Expression and identification of fusion proteins. a SDS-PAGE analysis of CSFV-E2 protein expression and purification. 1- supernatant from uninduced bacteria; 2- supernatant from induced bacteria; 3- inclusion bodies from uninduced bacteria; 4- inclusion bodies from induced bacteria; 5- empty vector control; 6- purified E2 protein. b SDS-PAGE analysis of PPV-VP2 protein expression and purification. 1- supernatant from uninduced bacteria; 2-supernatant from induced bacteria; 3- inclusion bodies from uninduced bacteria; 4- inclusion bodies from induced bacteria; 5- empty vector control; 6- purified VP2 protein. c SDS-PAGE analysis of JEV-EDIII protein expression and purification. 1- supernatant from uninduced bacteria; 2- supernatant from induced bacteria; 3- inclusion bodies from uninduced bacteria; 4- inclusion bodies from induced bacteria; 5- empty vector control: 6- purified EDIII protein. $\mathbf{d}$ SDS-PAGE analysis of PRRSV-N protein expression and purification. 1- supernatant from uninduced bacteria; 2- supernatant from induced bacteria; 3- inclusion bodies from uninduced bacteria; 4- inclusion bodies from induced bacteria; 5 . Control from empty vector; 6- purified N protein. e Western blot of bacterial lysates. After SDS-PAGE, the purified proteins were subject to western blotting using $6 \times$ His-tagged mAb as secondary antibody.1. E2 protein; 2. VP2 protein; 3. EDIII protein; 4. N protein; 5. empty vector control

PPV, JEV and PRRSV-positive sera showed fluorescent spots only at the corresponding protein positions.

Fifty clinical serum samples were tested using the chips under the optimized conditions; the test was done in triplicate with three technical repeats per test. The results showed that the coefficients of variation within a test were less than $2.5 \%$, and the coefficients of variation between tests were less than $3 \%$ (Table 2), demonstrating the repeatability and stability that the chip assay.

\section{Comparison by method of seroprevalence in clinical samples}

Two- hundred clinical samples were tested using the protein chip and commercial ELISA kits. The results demonstrate that for positive samples, the percent agreement between the methods was $100 \%$ for CSFV, $97.7 \%$ for PPV, 95.8\% for JEV, and 100\% PRRSV. For negative samples the agreement was 100, 86.2, 94.1, and $100 \%$, respectively (Table 3). 

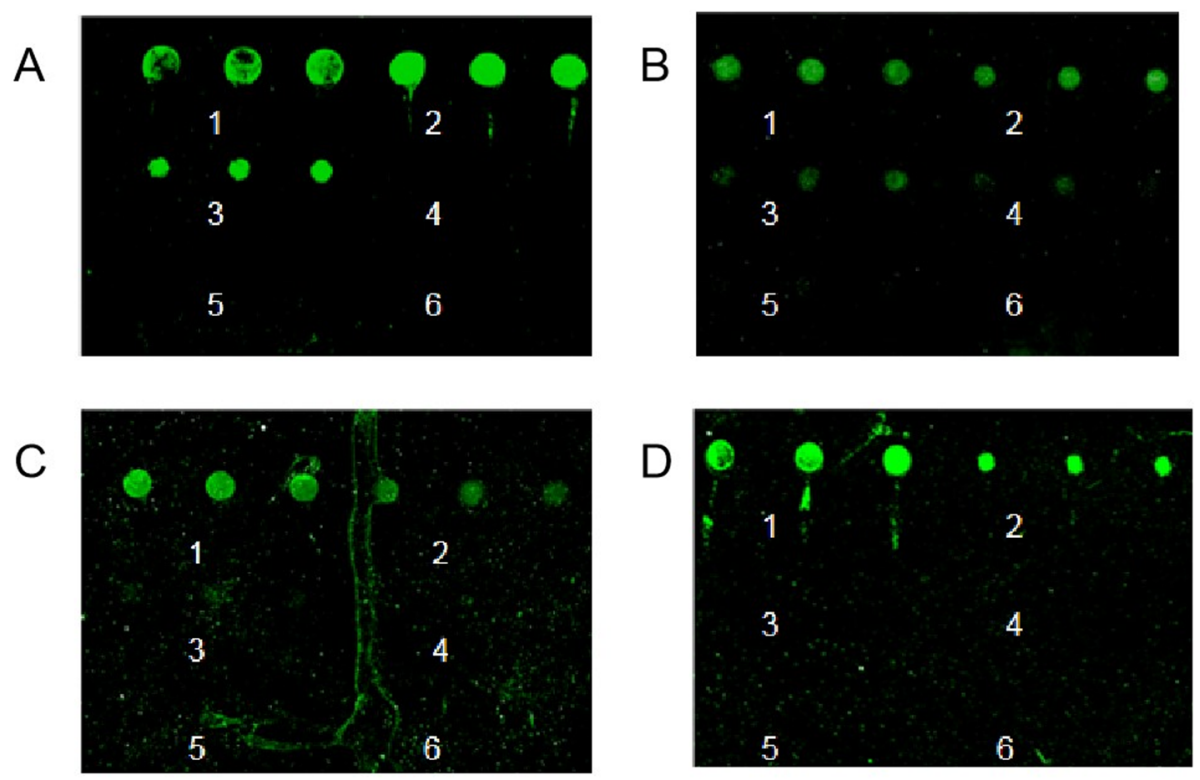

SNR value profile
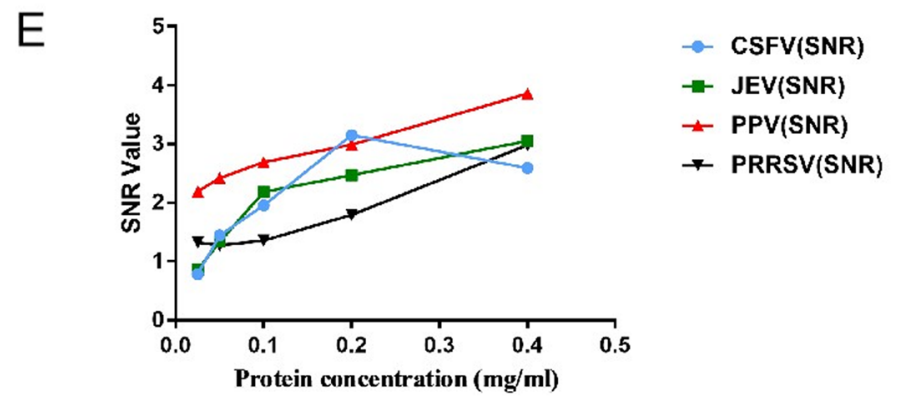

Fig. 2 Optimal antigen concentration. Each fusion protein was spotted on the epoxy slides at concentrations of 0.4, 0.2, 0.1, 0.05, and 0.025 mg/ $\mathrm{mL}$ in triplicate. Optimum concentration of a CSFV-E2, (B) PPV-VP2, c JE-EDIII and d PRRSV-N. Numbers indicate concentration 1, $0.4 \mathrm{mg} / \mathrm{mL} ; 2,0.2$ $\mathrm{mg} / \mathrm{mL} ; 3,0.1 \mathrm{mg} / \mathrm{mL} ; 4,0.05 \mathrm{mg} / \mathrm{mL} ; 5,0.025 \mathrm{mg} / \mathrm{mL}$; and 6, negative control. e SNR profile for each protein

\section{Discussion}

With the increasing scale and density of the pig industry, the damage from pig infectious diseases, especially viral infectious diseases, is increasing. Classical swine fever [18], porcine parvovirus disease [19, 20], Japanese encephalitis [21] and porcine reproductive and respiratory syndrome [22] are serious viral diseases on large-scale pig farms in China. Moreover, pigs infected with these viruses are often infected with other pathogens as well. The mixed infection of diseases not only brings huge economic losses to the breeding industry but also reduces the immune effect of the herd [3]. Although diagnostic methods have been established for each of these viral infections, screening cannot be done simultaneously for these and other pathogens [6, 23, 24]. For diagnostics, protein chips are not yet widely used for animal diseases because of theirs high preparation costs $[25,26]$. Our study expands the application of protein chips for diagnosing disease in pigs.
Early protein chips were of nitrocellulose or NC membrane (Nylon cellulose membrane) [17], due to the soft texture and space constraints of these materials, cross contamination often occurred between protein samples. Chip technology has continuously improved, and in this study, we used an epoxy chip. Epoxides react with various groups on the surface of proteins, such as hydroxyl, mercapto, carboxyl, without changing the properties of those proteins [27]. Compared with other chemically modified substrates, epoxy substrates have lower cost and are suitable for large-scale industrial production. In addition, compared with the ELISA assay, the biochip assay requires very low levels of proteins [28-30]. We used prokaryotically expressed CSFV-E2, PPV-VP2, JEVEDIII, and PRRSV-N proteins as the capture antigens to simultaneously screen serum samples for antibodies to these viruses. Cy3-labeled secondary antibody was used to visualize the results. Our chip assay had very good sensitivity and specificity, and performed well in 


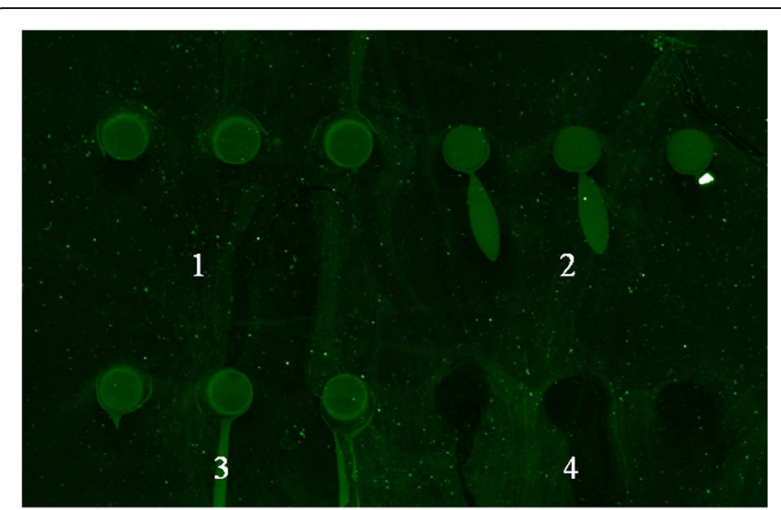

Fig. 3 Optimal print buffer. The protein samples of CSFV-E2 were diluted with $40 \%$ vol or commercial print buffer, or $50 \%$ vol homemade print buffer to the optimal concentration and spotted on epoxy chip. 1, 50\%vol commercial print buffer; $2,50 \% \mathrm{vol}$ homemade print buffer; $3,40 \%$ vol commercial print buffer; 4 , Negative control of BSA
Table 1 Cut-off value for determination of four viral antibodies

\begin{tabular}{lllll}
\hline & CSFV & PPV & JEV & PRRSV \\
\hline SNR & 1.78 & 2.35 & 3.38 & 1.58 \\
Positive criteria & SNR $>1.78$ & SNR $>2.35$ & SNR $>3.38$ & SNR1.58 \\
Negative criteria & SNR $<1.78$ & SNR $<2.35$ & SNR $<3.38$ & SNR $<1.58$ \\
\hline
\end{tabular}

accordance with commercial ELISA kits. We screened 200 clinical samples using both the protein chip and commercial ELISA kits. The coincidence rates of the positive samples were 95.8 to $100 \%$ and the coincidence rates of the negative samples were 86.2 to $100 \%$. We feel therefore, that our protein chip can replace ELISA kits as a diagnostic tool for identifying CSFV, PPV, JEV, and PRRSV infections.

\section{Conclusion}

In summary, we have prepared a protein biochip that can be used to screen for antibodies in clinical serum samples after mixed infection. The data show that this protein biochip is specific and sensitive. This work has

A

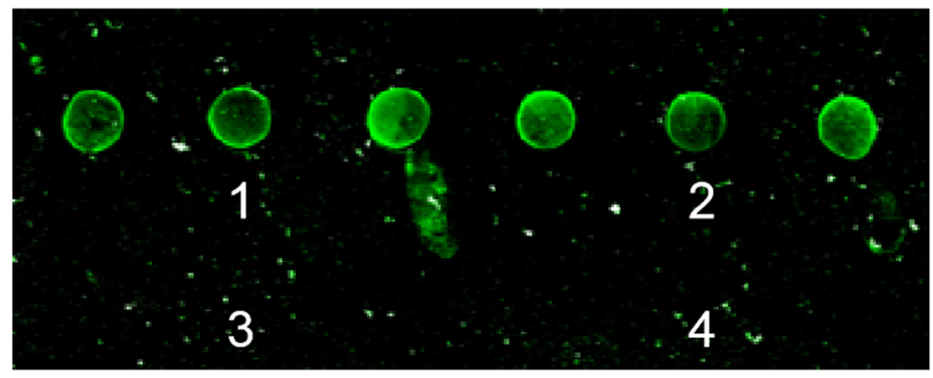

B

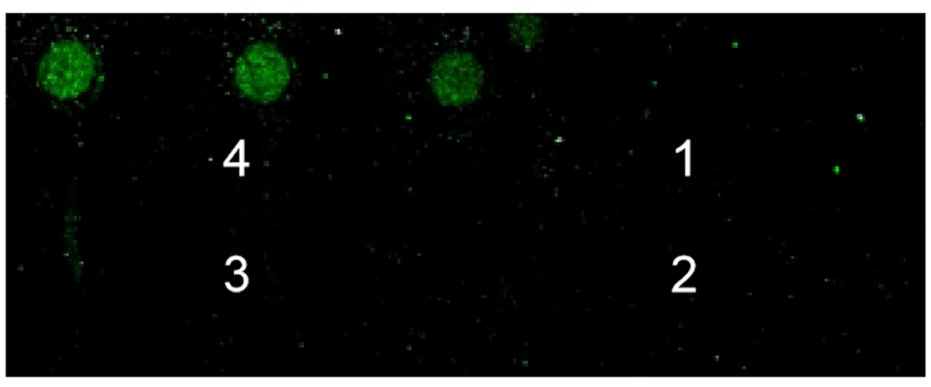

C

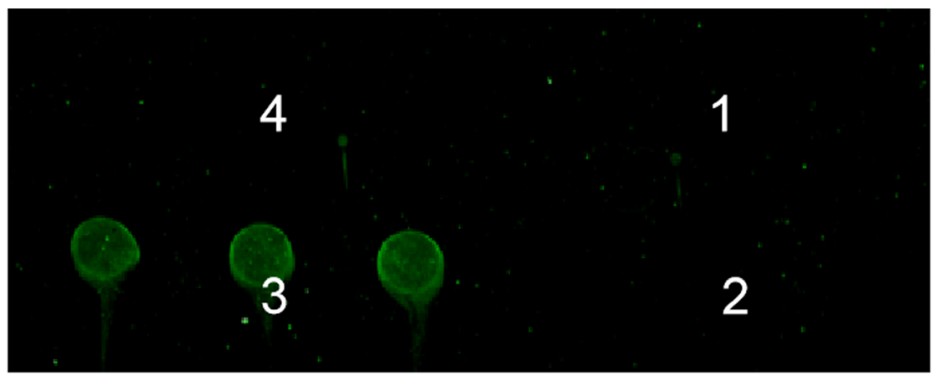

Fig. 4 Specificity of the chip assay. Proteins were printed in triplicate in an array (1, CSFV-E2; 2, PRRSV-N; 3, JEV-EDIII; 4, PPV-VP2) and each array was printed in triplicate. a Incubated with CSFV \& PRRSV positive serum; b Incubated with PPV positive serum; c Incubated with JEV positive serum 
Table 2 Stability of the protein chip

\begin{tabular}{|c|c|c|c|c|c|c|c|c|c|c|}
\hline & \multicolumn{5}{|c|}{ Intra-batch repeat } & \multicolumn{5}{|c|}{ Repeat between batches } \\
\hline & $\begin{array}{l}1 s t \\
\text { group }\end{array}$ & $\begin{array}{l}\text { 2nd } \\
\text { group }\end{array}$ & $\begin{array}{l}\text { 3rd } \\
\text { group }\end{array}$ & $\begin{array}{l}\text { Standard } \\
\text { deviation }\end{array}$ & $\begin{array}{l}\text { Coefficient of } \\
\text { variation(\%) }\end{array}$ & $\begin{array}{l}1 \text { st } \\
\text { group }\end{array}$ & $\begin{array}{l}\text { 2nd } \\
\text { group }\end{array}$ & $\begin{array}{l}\text { 3rd } \\
\text { group }\end{array}$ & $\begin{array}{l}\text { Standard } \\
\text { deviation }\end{array}$ & $\begin{array}{l}\text { Coefficient of } \\
\text { variation(\%) }\end{array}$ \\
\hline CSFV & 1.83 & 1.86 & 1.9 & 0.035 & 1.88 & 1.89 & 1.93 & 1.83 & 0.05 & 2.67 \\
\hline PPV & 3.13 & 3.2 & 3.09 & 0.056 & 1.74 & 3.15 & 3.25 & 3.22 & 0.05 & 1.6 \\
\hline JEV & 3.54 & 3.69 & 3.65 & 0.077 & 2.14 & 3.66 & 3.57 & 3.69 & 0.06 & 1.71 \\
\hline PRRSV & 2.37 & 2.29 & 2.34 & 0.04 & 1.73 & 2.38 & 2.28 & 2.31 & 0.05 & 2.2 \\
\hline
\end{tabular}

contributed to the development of high-density, integrated diagnostic biochips.

\section{Methods}

\section{Plasmid construction}

Using the sequences in GenBank as template, specific primer pairs (Table 4) were designed to amplify CSVFE2 (FJ598612.1), JEV-ED III (LC095865.1), and PRRSV$\mathrm{N}$ (KM252867.1). The three virus cDNAs stored in the laboratory were used to amplify the corresponding target genes. The amplicons were purified by AGE, digested by the restriction enzymes indicated in Table 1 and cloned into the corresponding sites of a pET-32a vector. The PPV VP2 gene (JQ710896.1) sequence (amino acids 156-438) was optimized using DNAStar software according to E. coli preference codon and then synthesized by the Jinkairui Company (Wuhan, China) (Table S1). The synthesized gene was cloned into a BamHI/Hind III digested pET-32a vector. All constructs were verified by restriction digestion, PCR, and DNA sequencing.

\section{Expression and purification of proteins}

The expression and purification of these four fusion proteins was carried out as described previously [31-33]. Briefly, BL21(DE3) cells (TsingKe Biotechnology Co., Ltd., Beijing, China) were transformed with each recombinant plasmid, cultured $37^{\circ} \mathrm{C}$ in LB (Luria Broth) medium supplemented with $100 \mu \mathrm{g} / \mathrm{mL}$ ampicillin until logarithmic phase (at $\mathrm{OD}_{600}$ of 0.6 ), then induced by IPTG at a final concentration of $0.2 \mathrm{mM}(\mathrm{mmol} / \mathrm{L})$ for 5 $\mathrm{h}$ at $37^{\circ} \mathrm{C}$. The re-suspended cells were lysed by sonication on ice $(8$ cycles $\times 1 \mathrm{~min} /$ cycle at intervals of $30 \mathrm{~s})$, then centrifuged for $15 \mathrm{~min}$ at $10,000 \mathrm{x}$ g. Supernatants and pellets (suspended in PBS (Phosphate buffered saline)) were collected, and analyzed by SDS-PAGE to access the solubility of each protein. Fusion proteins in inclusion bodies, were denatured overnight in $8 \mathrm{M}$ urea at $4{ }^{\circ} \mathrm{C}$, and remained in the supernatant after centrifugation. His-tagged fusion proteins were bound to HISTRAP HP (GE life, USA) and purified following the manufacturer's instructions. The freshly purified proteins were treated with Detoxi-Gel ${ }^{\mathrm{mi}}$ Endotoxin Removing Gel (Thermo, USA) according to the manufacturer's instructions, then aliquots and stored at $-80^{\circ} \mathrm{C}$. The protein concentration was measured by $\mathrm{BCA}$ protein quantification kit (Vazyme Biotechnology Co., Ltd., China).

\section{Preparation of the protein chip}

Figure 5 illustrates the following steps. Each purified protein in $\mathrm{PBS} / 2 \%$ BSA was diluted to $0.4,0.2,0.05$, and $0.025 \mathrm{mg} / \mathrm{mL}$ with $2 \mathrm{X}$ printing buffer (Capital Biotechnology Co., Ltd. Company, China). Each dilution of each protein was printed in triplicate onto the chip using a SmartArrayer ${ }^{\mathrm{Tm}}$ microarray spotter (Capital Biotechnology Co., Ltd. Beijing, China). The chips were placed in an incubator overnight at $37^{\circ} \mathrm{C}$ for $10 \mathrm{~h}$. The chips were then washed with PBST (Phosphate buffered salineTwen-20) and distilled water for $5 \mathrm{~min}$ each, then blocked for $2 \mathrm{~h}$ at $37^{\circ} \mathrm{C}$ with $2 \%$ BSA (Shanghai Biotech Biotechnology Co., Ltd., China) in PBS. After washing with PBST, the chip was placed in a drying tube and centrifuged at $1000 \mathrm{rpm}$ for $5 \mathrm{~min}$, then incubated with clinical serum (Shengtaiyuan Agriculture and Animal Husbandry Development Co., Ltd. Nanjing,China) and incubated for $1 \mathrm{~h}$ at $37^{\circ} \mathrm{C}$. The chips were washed again

Table 3 Comparison between the results of protein chip and commercial ELISA kit

\begin{tabular}{|c|c|c|c|c|c|c|c|c|}
\hline & \multicolumn{2}{|l|}{ CSFV } & \multicolumn{2}{|l|}{ PPV } & \multicolumn{2}{|l|}{ JEV } & \multicolumn{2}{|l|}{ PRRSV } \\
\hline & Chip & ELISA & Chip & ELISA & Chip & ELISA & Chip & ELISA \\
\hline Total (no.) & 200 & & 200 & & 200 & & 200 & \\
\hline Positive (no.) & 183 & 183 & 175 & 171 & 120 & 115 & 193 & 193 \\
\hline Negative (no.) & 17 & 17 & 25 & 29 & 80 & 85 & 7 & 7 \\
\hline Positive (\%) & $91.50 \%$ & $91.50 \%$ & $87.50 \%$ & $85.50 \%$ & $60.00 \%$ & $57.50 \%$ & $96.50 \%$ & $96.50 \%$ \\
\hline Negative (\%) & $9.50 \%$ & $9.50 \%$ & $12.50 \%$ & $14.50 \%$ & $40.00 \%$ & $42.50 \%$ & $3.50 \%$ & $3.50 \%$ \\
\hline
\end{tabular}


Table 4 Primers used in the study

\begin{tabular}{|c|c|c|c|c|}
\hline & Specific primer sequence $\left(5^{\prime} \rightarrow 3^{\prime}\right)$ & Restriction sites & Amplification site & Fragment size \\
\hline \multirow[t]{2}{*}{ CSFV } & CSFV-E2-F:5'-TGACTCTAGATATTTGGCATCATTGCATAAGGGGG-3' & Xbal & $193-530$ & $338 \mathrm{bp}$ \\
\hline & CSFV-E2-R:5'-TGACGGTACCGATCTTCATTITCCACTGTGGTGG-3' & Kpnl & & \\
\hline \multirow[t]{2}{*}{ JEV } & JEV-EDIII-F:5'-TGACGATATCCACCTGAAATGCAGGCTAAAAATGG-3' & EcoRV & 849-1304 & $455 \mathrm{bp}$ \\
\hline & JEV-EDIII-R:5'-TGACAAGCTTGAATACCCCTCCAATGGAGCC-3' & HindllI & & \\
\hline \multirow[t]{2}{*}{ PRRSV } & PRRSV-N-F:5'-TGACGGATCCATGCCAAATAACAACGGCAGAC-3' & BamHI & $1-372$ & $372 \mathrm{bp}$ \\
\hline & PRRSV-N-R:5'-TGACCTCGAGTCATGCTGAGGGTGGTGTT-3' & Xhol & & \\
\hline \multirow[t]{2}{*}{ PPV } & PPV-VP2-F:5'-TGACGGATCCAGCGCAACCAGTCCG-3' & BamHI & amino acids $156-438$ & $849 \mathrm{bp}$ \\
\hline & PPV-VP2-R:5'-TGACAAGCTTCATATTGCTITTACCACCAATCGGA-3' & HindIII & & \\
\hline
\end{tabular}

and incubated with 1:600 Cy3 labeled goat anti-pig IgG (Immune Jackson, 138,102, USA) for $45 \mathrm{~min}$ at $37^{\circ} \mathrm{C}$ in darkness. Chips were washed again three times in PBST then scanned and analyzed with a CapitalBio Luxscan$10 \mathrm{~K} / \mathrm{A}$ chip scanner.

\section{Parameter optimization}

\section{Concentration of antigen}

In serological assays, antigen concentration has a great impact on the specificity and sensitivity of the reaction; high signal to noise ratios are the result of suboptimal concentrations. Each of the purified proteins were diluted to $0.4,0.2,0.1,0.05$, and 0.025 $\mathrm{mg} / \mathrm{mL}$ with $2 \times$ printing buffer, $2 \%$ BSA was the negative control, then spotted onto the epoxy-based slides (Capital Biotechnology Co., Ltd. Beijing, China).

\section{Concentration of printing buffer}

The concentration of printing buffer affects whether a stable protein spot can be formed. Each of the purified proteins were diluted with PBS containing $40 \%$ or $50 \%$ vol commercial printing buffer and $50 \%$ homemade buffer (PBST + 20\% glycerin).

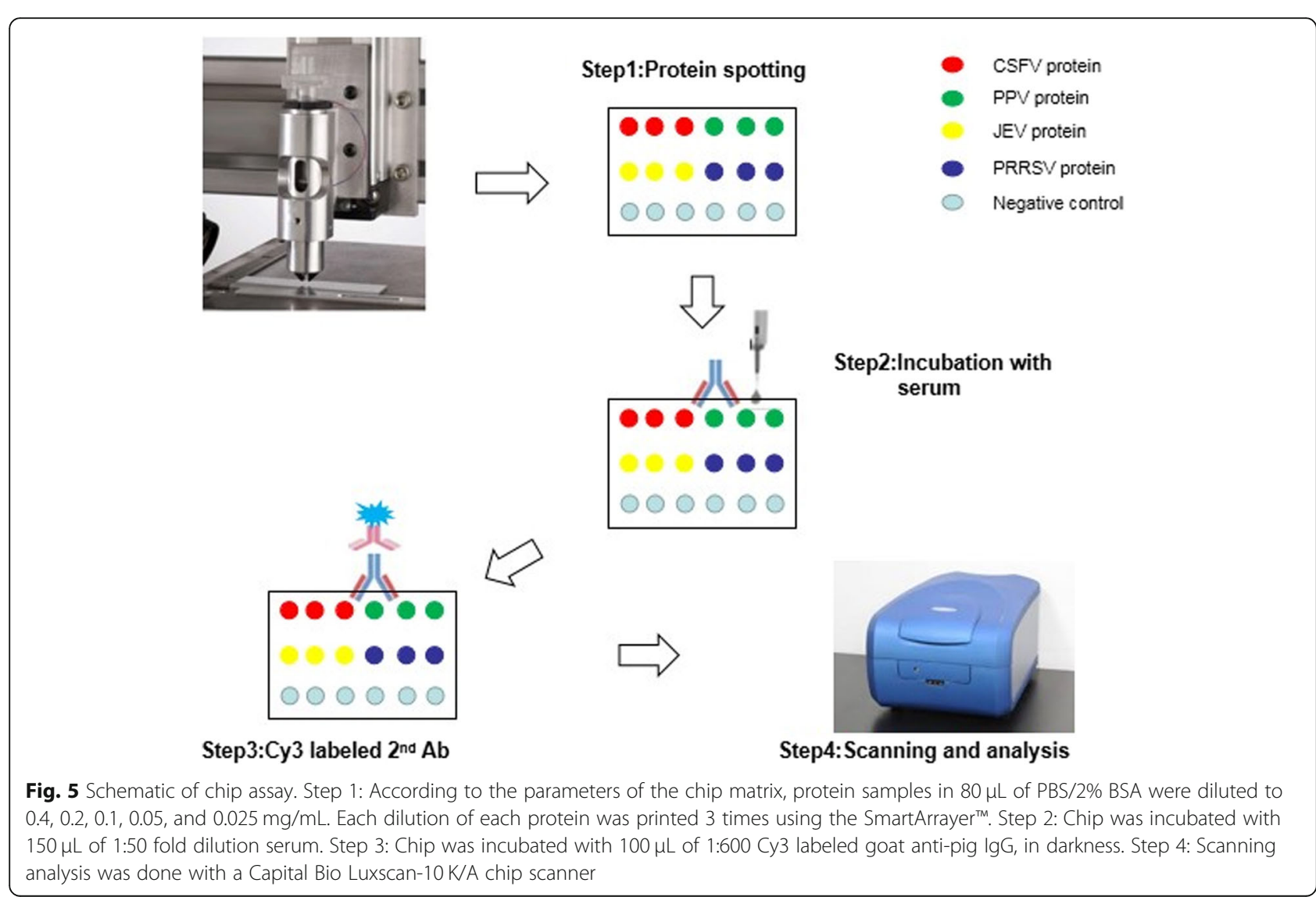




\section{Dilution of primary antibody and incubation time} Positive sera against CSFV, PPV, JEV or PRRSV were diluted 2, 5, 10, 50 and 100-fold in PBST and incubated with chips for 1 or $2 \mathrm{~h}$ at $37^{\circ} \mathrm{C}$ to determine the best dilution of primary antibody and incubation time.

\section{Dilution of secondary antibody and incubation time}

Cy3 labeled fluorescent secondary antibodies were diluted 100, 200, 500, 600 and 800-fold, and incubated with chips for 30,45 , or $60 \mathrm{~min}$ at $37^{\circ} \mathrm{C}$ to determine the optimal dilution and incubation time.

\section{The cut-off value of detection}

Twenty serums known to be negative for CSFV, PPV, JEV and PRRSV were 50-fold diluted and then were incubated with the prepared protein chips for $1 \mathrm{~h}$ at $37^{\circ} \mathrm{C}$. The CaptialBio Luxscan-10 K/A chip scanner was used to calculate the SNR value (median signal intensity to background median) and determine the cut-off value for detection of each viral protein.

\section{Specificity and repeatability}

The four fusion proteins were printed in triplicate, at their optimized concentration, in an array and the array was printed in triplicate. Each array was incubated with a specific protein-positive serum. In addition to 50 clinical serum samples were tested three times, each test contained three technical repeats.

\section{Method caparison using clinical serum samples}

Two-hundred pig serum samples were tested using the optimized conditions of the protein chip and commercial ELISA kits according to the manufacturer's instructions. (CSFV and PRRSV ELISA kits; IDEXX, USA); PPV and JEV ELISA kits;(Keqian Biological Co., Ltd., Wuhan, China).

\section{Supplementary information}

Supplementary information accompanies this paper at https://doi.org/10. 1186/s12917-020-02375-7.

\section{Additional file $\mathbf{1}$ Table S1. The optimized gene sequence of PPV-VP2}

\section{Abbreviations}

IPTG: Isopropyl $\beta$-D-1-Thiogalactopyranoside; ELISA: Enzyme-linked immunosorbent assay; PCR: Polymerase chain reaction; vol: Volume; BSA: Bovine serum albumin; NC: Nylon cellulose membrane; $\mathrm{mM}$ : $\mathrm{mmol} / \mathrm{L}$; PBS: Phosphate buffered saline; PBST: Phosphate buffered saline-Twen-20; LB: Luria Broth

\section{Acknowledgments}

We thank Elizabeth Wills from Cornell University for critical reading and editing of the manuscript.

\section{Consent to publication}

Not applicable Competing interest.

\section{Authors' contributions}

BZ designed and directed the study. YW, XDW and JFH performed the experiment and collected the resulting data. YW and XBH analyzed the data. $\mathrm{YW}, \mathrm{JC}$ and $\mathrm{XBH}$ drafted the first vision of the manuscript. JFH and $\mathrm{XBH}$ provided protein chip instrument and guide use. BZ critically revised the manuscripts. All the participants carefully reviewed this vision manuscript. All authors have read and approved the manuscript, and ensure that this is the case.

\section{Funding}

This work and the writing of the manuscript were financially supported by the National Key Research and Development Program of China-Multi-basic biochip technology research project for important swine disease

(2016YFD0500701-3). The funder had no role in the design of the collection, analysis, and interpretation of data.

\section{Availability of data and materials}

Raw data is available from the corresponding author on reasonable request.

\section{Ethics approval and consent to participate}

This study was carried out in strict accordance with the recommendations in the "Guidelines for the Care and Use of Laboratory Animals" by the Ministry of Health of China. The protocol for this study was reviewed and approved by the Institutional Animal Care and Use Committee of Nanjing Agricultural University. Clinical serum samples have obtained written informed consent from the farmer. This study minimized animal suffering during sample collection.

\section{Competing interests}

The authors declare that they have no competing interests.

\section{Author details}

${ }^{1} \mathrm{MOE}$ Joint International Research Laboratory of Animal Health and Food Safety, College of Veterinary Medicine, Nanjing Agricultural University, Nanjing 210095, China. ${ }^{2}$ College of Veterinary Medicine, Sichuan Agricultural University, Chengdu 611130, China.

Received: 13 February 2020 Accepted: 14 May 2020

Published online: 26 May 2020

\section{References}

1. Hause BM, Collin EA, Peddireddi L, Yuan F, Chen Z, Hesse RA, Gauger PC, Clement T, Fang Y, Anderson G. Discovery of a novel putative atypical porcine pestivirus in pigs in the USA. J Gen Virol. 2015;96(10):2994-8.

2. Chen N, Huang Y, Ye M, Li S, Xiao Y, Cui B, Zhu J. Co-infection status of classical swine fever virus (CSFV), porcine reproductive and respiratory syndrome virus (PRRSV) and porcine circoviruses (PCV2 and PCV3) in eight regions of China from 2016 to 2018. Infect Genet Evol. 2019;68:127-35.

3. Kumar N, Sharma S, Barua S, Tripathi BN, Rouse BT. Virological and immunological outcomes of Coinfections. Clin Microbiol Rev. 2018;31(4): e00111-7.

4. Bown P, Armstrong D. Emerging disease threat for pigs? Vet Rec. 2009; 165(14):417-8

5. Goraya MU, Ziaghum F, Chen S, Raza A, Chen Y, Chi X. Role of innate immunity in pathophysiology of classical swine fever virus infection. Microb Pathog. 2018;119:248-54.

6. Panyasing $Y$, Kedkovid R, Thanawongnuwech R, Kittawornrat A, Ji J, Gimenez-Lirola L, Zimmerman J. Effective surveillance for early classical swine fever virus detection will utilize both virus and antibody detection capabilities. Vet Microbiol. 2018;216:72-8.

7. Tong GZ, Zhou YJ, Hao XF, Tian ZJ, An TQ, Qiu HJ. Highly pathogenic porcine reproductive and respiratory syndrome, China. Emerg Infect Dis. 2007:13(9):1434-6.

8. Khodakov DA, Zakharova NV, Gryadunov DA, Filatov FP, Zasedatelev AS, Mikhailovich VM. An oligonucleotide microarray for multiplex real-time PCR identification of HIV-1, HBV, and HCV. Biotechniques. 2008;44(2):241-6 248.

9. Kim SW, Kim MG, Jung HA, Lee KH, Lee HS, Ro HS. An application of protein microarray in the screening of monoclonal antibodies against the oyster mushroom spherical virus. Anal Biochem. 2008;374(2):313-7.

10. Spiess B, Seifarth W, Hummel M, Frank O, Fabarius A, Zheng C, Morz H, Hehlmann R, Buchheidt D. DNA microarray-based detection and 
identification of fungal pathogens in clinical samples from neutropenic patients. J Clin Microbiol. 2007:45(11):3743-53.

11. Park WY. High throughput genotyping for genomic cohort study. J Prev Med Public Health. 2007;40(2):102-7.

12. Andrade DC, Borges IC, Laitinen H, Ekstrom N, Adrian PV, Meinke A, Barral A, Nascimento-Carvalho CM, Kayhty H. A fluorescent multiplexed bead-based immunoassay (FMIA) for quantitation of IgG against Streptococcus pneumoniae, Haemophilus influenzae and Moraxella catarrhalis protein antigens. J Immunol Methods. 2014;405:130-43.

13. Lawson S, Lunney J, Zuckermann F, Osorio F, Nelson E, Welbon C, Clement T, Fang Y, Wong S, Kulas K, et al. Development of an 8-plex Luminex assay to detect swine cytokines for vaccine development: assessment of immunity after porcine reproductive and respiratory syndrome virus (PRRSV) vaccination. Vaccine. 2010;28(32):5356-64.

14. Xu QY, Sun EC, Feng YF, Li JP, Lv S, Zhang Q, Wang HX, Zhang JK, Wu DL. Development of a novel protein chip for the detection of bluetongue virus in China. J Virol Methods. 2016;234:28-33.

15. Wei J, Guo N, Liang J, Yuan P, Shi Q, Tang X, Yu L. DNA microarray gene expression profile of mycobacterium tuberculosis when exposed to osthole. Pol J Microbiol. 2013;62(1):23-30.

16. Ramachandran N, Raphael JV, Hainsworth E, Demirkan G, Fuentes MG, Rolfs A, Hu Y, LaBaer J. Next-generation high-density self-assembling functional protein arrays. Nat Methods. 2008;5(6):535-8.

17. Tabakman SM, Lau L, Robinson JT, Price J, Sherlock SP, Wang H, Zhang B, Chen Z, Tangsombatvisit S, Jarrell JA, et al. Plasmonic substrates for multiplexed protein microarrays with femtomolar sensitivity and broad dynamic range. Nat Commun. 2011;2:466.

18. Hahn J, Park SH, Song JY, An SH, Ahn BY. Construction of recombinant swinepox viruses and expression of the classical swine fever virus E2 protein. J Virol Methods. 2001;93(1-2):49-56.

19. Cartwright SF, Lucas M, Huck RA. A small haemagglutinating porcine DNA virus. I. Isolation and properties. J Comp Pathol. 1969;79(3):371-7.

20. Johnson RH, Collings DF. Experimental infection of piglets and pregnant gilts with a parvovirus. Vet Rec. 1969:85(16):446-7.

21. Garjito TA, Widiarti, Anggraeni YM, Alfiah S, Tunggul Satoto TB, Farchanny A, Samaan G, Afelt A, Manguin S, Frutos R, et al. Japanese encephalitis in Indonesia: An update on epidemiology and transmission ecology. Acta Trop. 2018:187:240-7.

22. Guo B, Lager KM, Schlink SN, Kehrli ME Jr, Brockmeier SL, Miller LC, Swenson SL, Faaberg KS. Chinese and Vietnamese strains of HP-PRRSV cause different pathogenic outcomes in United States high health swine. Virology. 2013; 446(1-2):238-50

23. Plagemann PG. Complexity of the single linear neutralization epitope of the mouse arterivirus lactate dehydrogenase-elevating virus. Virology. 2001; 290(1):11-20.

24. Sarkar A, Taraphdar D, Mukhopadhyay SK, Chakrabarti S, Chatterjee S. Serological and molecular diagnosis of Japanese encephalitis reveals an increasing public health problem in the state of West Bengal, India. Trans R Soc Trop Med Hyg. 2012;106(1):15-9.

25. Chang YJ, Ho CY, Chang CH. Influence of material properties upon immobilization of histidine-tagged protein on Ni-co coated chip. Mater Sci Eng C Mater Biol Appl. 2014;37:369-73.

26. Zhang B, Kumar RB, Dai H, Feldman BJ. A plasmonic chip for biomarker discovery and diagnosis of type 1 diabetes. Nat Med. 2014;20(8):948-53.

27. Wang $Y$, Ji $Y$, Zhao $Y$, Kong $Y$, Gao M, Feng $Q$, Wu Y, Yang Y. Effects of surface functional groups on proliferation and biofunction of Schwann cells. J Biomater Appl. 2016;30(10):1494-504.

28. Rissin DM, Kan CW, Song L, Rivnak AJ, Fishburn MW, Shao Q, Piech T, Ferrell EP, Meyer RE, Campbell TG, et al. Multiplexed single molecule immunoassays. Lab Chip. 2013;13(15):2902-11.

29. Wang C, Shi Y, Wang J, Pang J, Xia XH. Ultrasensitive protein concentration detection on a micro/nanofluidic enrichment chip using fluorescence quenching. ACS Appl Mater Interfaces. 2015;7(12):6835-41.

30. Dai Z, Shu X, Li G, Xi W. Performance evaluation of protein Chip assay for rapid diagnosis of hepatitis $C$ virus infection in injection drug abusers. Clin Lab. 2018;64(4):527-34.

31. Panavas T, Sanders C, Butt TR. SUMO fusion technology for enhanced protein production in prokaryotic and eukaryotic expression systems. Methods Mol Biol. 2009;497:303-17.

32. Tropea JE, Cherry S, Waugh DS. Expression and purification of soluble his(6)tagged TEV protease. Methods Mol Biol. 2009;498:297-307.
33. Wang K, Holtz KM, Anderson K, Chubet R, Mahmoud W, Cox MM Expression and purification of an influenza hemagglutinin--one step closer to a recombinant protein-based influenza vaccine. Vaccine. 2006;24(12): $2176-85$.

\section{Publisher's Note}

Springer Nature remains neutral with regard to jurisdictional claims in published maps and institutional affiliations.
Ready to submit your research? Choose BMC and benefit from:

- fast, convenient online submission

- thorough peer review by experienced researchers in your field

- rapid publication on acceptance

- support for research data, including large and complex data types

- gold Open Access which fosters wider collaboration and increased citations

- maximum visibility for your research: over $100 \mathrm{M}$ website views per year

At $\mathrm{BMC}$, research is always in progress.

Learn more biomedcentral.com/submissions 